\title{
Troubled waters - where is the bridge? Confronting marine plastic pollution from international watercourses
}

\author{
Linda Finska and Julie Gjørtz Howden \\ Correspondence \\ Email: linda.finska@uit.no
}

A considerable volume of marine plastic pollution derives from watercourses, and many of the world's largest and most heavily polluted, watercourses are international. In spite of the clear factual link between the utilization and protection of international watercourses and marine plastic pollution there is hardly any interaction between the legal sub-fields of international water law and marine environmental law. This lack of interaction also reflects the absence of a global treaty, or even a shared global understanding, of the environmental threat from plastic pollution and the universal responsibility this generates also for landlocked States. This article investigates the possibilities for more integrated measures to prevent pollution of international watercourses and oceans, and argues that regimes within international water law and marine environmental law must cooperate to create awareness of the plastic pollution risk from watercourses and take steps to harmonize their legal rules and policies to contribute to the control and mitigation of marine plastic pollution. Regional coordination, such as improved cooperation between the regional seas organizations and river basin organizations, could provide a tool to better address transboundary sources of plastic. Potentially, such developments could be adopted to control marine plastic pollution from the most heavily polluted international watercourses.

\section{INTRODUCTION}

Riverine inputs of plastics are a major threat to the marine environment, according to recent studies. ${ }^{1}$ It is characteristic for marine plastic pollution ${ }^{2}$ that the problem starts on land, mostly due to inadequate waste management. Plastics are transported via rivers that often cross several boundaries, and flow into the marine environment of coastal States. Finally, plastics end up further out in the oceans due to currents and winds, or wash up on beaches that may be located far from where the plastics originated. The nature of the problem signifies that no one regime exists in international law that could regulate all aspects of it. More and more complex cooperation is needed between different regimes to construct an effective legal response and permanently prevent plastics polluting the marine environment. In this article, we focus on the interaction between marine environmental law and international water law in dealing with marine plastic pollution. The purpose is to draw attention to the physical and legal linkages between plastics, watercourses and oceans by mapping out and discussing the current legal frameworks and the lack of clear cooperative initiatives.

No binding or non-binding legal instrument explicitly regulates the prevention of marine plastic pollution on a global level. Nonetheless, multiple instruments are applicable to it more generally. We use the most recent scientific knowledge on riverine inputs of plastics as a starting

\footnotetext{
1 See C Schmidt, T Krauth and S Wagner, 'Export of Plastic Debris by Rivers into the Sea' (2017) 51 Environmental Science \& Technology 12246; LCM Lebreton et al, 'River Plastic Emissions to the World's Oceans' (2017) 8 Nature Communications 1.

${ }^{2}$ In this article, we use 'marine plastic pollution' when referring to plastics that end up in the oceans, 'riverine inputs of plastics' when referring to plastics that reach the oceans via rivers, and 'plastic' or 'plastics' when referring to the material itself. Marine plastic pollution falls under the more general categories of 'litter' and 'pollution'. We use these expressions only when they are referred to in other sources, and when encompassing plastics.
} 
point and as a source of inspiration to construct the legal research questions and the analysis of current marine environmental law, international water law, and their relationship in the context of combatting marine plastic pollution. We also argue for pivotal improvements to the current legal framework and for interaction between different sub-fields of international environmental law. The scope of the article covers analysing the main instruments of international law concerned with protecting the marine environment from land-based sources of pollution and relating to protecting the marine environment from pollution of international watercourses, as well as concepts of general international law, such as fragmentation, cooperation and interaction between different regimes of international law. On a regional level, we examine the major polluting international watercourses and the relevant marine areas thereof, to determine whether there are legislative and institutional initiatives for cooperation to combat marine plastic pollution. This analysis is based on a scientific modelling of riverine inputs of plastics, regional seas instruments and information on river basin commissions.

Section 2 investigates the obligations and the nature of interactions between the legal regimes of marine environmental law and international water law. In marine environmental law, rivers are generally considered to be land-based sources of pollution. ${ }^{3}$ The general principles for assessing and controlling pollution in the Stockholm Declaration, which first put land-based sources of pollution on the international agenda, ${ }^{4}$ formed the basis for part XII of the 1982 United Nations Convention for the Law of the Sea (LOSC) and the United Nations Environment Programme's (UNEP) Regional Seas Programme (RSP) ${ }^{5}$ and paved the way for soft law instruments dealing with land-based activities such as the 1985 Montreal Guidelines and the Global Programme of Action for the Protection of the Marine Environment from Land-Based Activities (GPA). ${ }^{6}$ When examining how international water law has contributed to protecting the marine environment, we take a closer look at the contributions from the United Nations Convention on the Non-navigational Uses of International Watercourses (UNWC) and the United Nations Economic Commission for Europe's Convention on the Protection and Use of Transboundary Watercourses and International Lakes (UNECE Water Convention). In Section 3 , we take a regional approach and look more closely at areas that can be considered 'hotspots' of riverine inputs of marine plastic pollution. The purpose of this exercise is to show to what extent an integrated approach to protect river and marine environments is actually used in these hotspot regions. In Section 4, we analyse the dynamics between marine environmental law and international water law and the reasons behind any shortcomings in their interaction. Finally, Section 5 presents conclusions and suggestions for the future.

\section{OBLIGATIONS AND INTERACTION BETWEEN LEGAL REGIMES}

\subsection{How has international marine environmental law taken into account international watercourses?}

Marine environmental law is concerned with protecting and preserving the marine environment. The LOSC sets general obligations to States relating to land-based sources of pollution, thus providing guidance relating to activities not only occurring in or on the oceans and seas but also

\footnotetext{
${ }^{3}$ United Nations Convention on the Law of the Sea (adopted 10 December 1982, entered into force 16 November 1994) 1833 UNTS 3 (LOSC) art 207(1).

${ }^{4}$ DL VanderZwaag, PG Wells and J Karau, 'The Global Programme of Action for the Protection of the Marine Environment from Land-Based Activities: A Myriad of Sounds, Will the World Listen?' (1998) 13 Ocean Yearbook 183, 184.

${ }^{5}$ PW Birnie, AE Boyle and C Redgwell, International Law \& the Environment (3rd edn, Oxford University Press 2009) 382.

${ }^{6}$ VanderZwaag et al. (n 4) 184.
} 
to activities on land. ${ }^{7}$ Part XII of the LOSC is generally accepted to be part of customary international law, ${ }^{8}$ and therefore the environmental provisions concerning pollution apply to all States. The LOSC is the only binding global instrument explicitly addressing land-based sources of pollution, and its definition of pollution implicitly encompasses plastics. ${ }^{9}$

Articles 207 and 213 of the LOSC provide the international legal foundation for the protection of the marine environment from land-based sources. Pursuant to Article 207(1) of the LOSC, 'States shall adopt laws and regulations to prevent, reduce and control pollution of the marine environment from land-based sources, including rivers, estuaries ... taking into account internationally agreed rules, standards and recommended practices and procedures'. Thus, the general obligation to prevent, reduce and control pollution from land-based sources explicitly includes rivers and estuaries as sources of pollution threatening the marine environment. Pursuant to Article 213, States must enforce the laws and regulations that have been adopted in accordance with Article 207, adopt laws and regulations, and take other necessary measures to implement the international rules and standards.

Articles 207 and 213 of the LOSC, however, have been criticized for being too vague and inadequate to provide practical guidance for States. They do not point out the internationally agreed rules and standards or other measures to be taken into consideration, let alone the minimum standard of protection required, and they do not refer to any criteria that would help to measure the suitability of these legislative or other actions. ${ }^{10}$ What also follows from the formulation of these provisions is a problem of circularity, because the only generally accepted international rules that can be found are the ones referred to in the LOSC, and the LOSC again presumes the existence of external rules. ${ }^{11}$ This critique also applies to rivers and estuaries: other than mentioning them as sources, the LOSC does not provide any further guidance on how to deal with these sources. It should also be noted that although watercourses transport pollution from land to the oceans, the actual source of pollution are activities on land and not the rivers as such. Another weak point of Articles 207 and 213 is that they incorporate all possible pollutants deriving from land under one all-encompassing article. Multiple pollutant substances are threatening the oceans and controlling these pollutants has no 'one size fits all' solution. Marine plastic pollution has its unique characteristics and only by being aware of the factual problems can the legal solutions be constructed.

Over the past decades, the international community has adopted a soft law approach to target land-based activities threatening the marine environment. ${ }^{12}$ The Montreal Guidelines were adopted in 1985 as the first global attempt to address protection of the marine environment from land-based activities. ${ }^{13}$ The Guidelines acknowledged that pollution enters the oceans via watercourses. ${ }^{14}$ Although States generally have failed to implement the Guidelines, they can provide valuable input to the implementation of the Global Programme of Action for the

\footnotetext{
${ }^{7}$ D Osborn, 'Land-Based Pollution and the Marine Environment' in R Rayfuse (ed), Research Handbook on International Marine Environmental Law (Edward Elgar 2015) 81, 85.

${ }^{8}$ Birnie et al (n 5) 387-390; CJ Joyner and S Frew, 'Plastic Pollution in the Marine Environment' (1991) 22 Ocean Development and International Law 33, 53-54.

${ }^{9}$ LOSC (n 3) art 1(1)(4) defines pollution of the marine environment as 'the introduction by man, directly or indirectly, of substances into the marine environment which results or is likely to result in such deleterious effects as harm to living resources and marine life, hazards to human health, hindrance to marine activities, including fishing and other legitimate uses of the sea, impairment of quality for use of sea water and reduction of amenities'. ${ }^{10}$ D Hassan, Protecting the Marine Environment from Land-Based Sources of Pollution: Towards Effective International Cooperation (Ashgate 2006) 82.

${ }^{11}$ ML McConnell and E Gold, 'The Modern Law of the Sea: Framework for the Protection and Preservation of the Marine Environment' (1991) 23 Case Western Reserve Journal of International Law 83, 101.

${ }^{12}$ VanderZwaag et al (n 4) 184.

13 UNEP, 'Protection of the Marine Environment against Pollution from Land-Based Sources (Montreal Guidelines)' (1985) 14 Environmental Policy and Law 77.

14 ibid.
} 
Protection of the Marine Environment from Land-Based Activities, ${ }^{15}$ especially when it comes to the interface between international watercourses and oceans. The Guidelines explicitly state that land-locked States 'should co-operate in preventing, reducing and controlling pollution of the marine environment originating or partially originating from releases within their territory into or reaching water basins or watercourses flowing into the marine environment'. ${ }^{16}$ Watercourses are also explicitly addressed in the Guidelines: 'If discharges of a watercourse which flows through the territories of two or more States or forms a boundary between them are likely to cause pollution of the marine environment, the States concerned should co-operate in taking necessary measures to prevent, reduce and control such pollution. ${ }^{17}$ It is evident from these Guidelines that cooperation is essential for preventing, reducing and controlling transboundary pollution, such as plastics. Watercourses and their ability to transport pollution means that not only coastal States should cooperate to protect the marine environment, but also all landlocked States, including those upstream of an international watercourse.

Following the Guidelines, the GPA was established in 1995 with the aim 'to be a source of conceptual and practical guidance to be drawn upon by national and/or regional authorities in devising and implementing sustained action to prevent, reduce, control and/or eliminate marine degradation from land-based activities'. ${ }^{18}$ Currently the GPA is the most developed instrument to address activities on land and it explicitly deals with litter, the category under which plastics fall. ${ }^{19}$ Under the auspices of the GPA, a global multi-stakeholder partnership on marine litter was established in 2012 as it was deemed to merit particular attention. ${ }^{20}$

Since the LOSC does not provide any guidance on how to deal with pollution deriving from watercourses, the GPA can offer insight on this topic. The GPA stresses that there should be cooperation between watercourse States and the marine regions where the watercourses terminate, and has adopted the ecosystem approach and the integrated coastal and river basin management approach (ICARM). ${ }^{21}$ The GPA also links itself to the UNEP Regional Seas Programme, ${ }^{22}$ which has become an important channel to implement Part XII of the LOSC, especially the provisions on land-based pollution. ${ }^{23}$

The GPA encourages regional and sub-regional cooperation as a means for States to support the implementation of national programmes of actions under the GPA and to harmonize their measures to fit the environmental circumstances in particular geographic areas. ${ }^{24}$ The link between watercourses and oceans is also recognized on a regional level and States are to 'ensure close collaboration between the national and regional focal points and regional economic groupings, other relevant regional and international organizations, development banks and

\footnotetext{
${ }^{15}$ C Williams and B Davis, 'Land-based Activities: What Remains to Be Done' (1995) 29 Ocean \& Coastal Management 207, 210.

${ }^{16}$ UNEP (n 13) 77-78.

17 ibid 78.

${ }^{18}$ UNEP 'Intergovernmental Conference to Adopt a Global Programme of Action for the Protection of the Marine Environment from Land-Based Activities' UN Doc UNEP(OCA)/LBA/IG.2/7 (5 December 1995) 9.

19 ibid 54-56.

${ }^{20}$ UNEP 'Intergovernmental Review Meeting on the Implementation of the Global Programme of Action for the Protection of the Marine Environment from Land-Based Activities. Third Session' UN Doc UNEP/GPA/IGR.3/6 (26 January 2012) 4, 7, 11.

${ }^{21}$ UNEP 'Combating Marine Plastic Litter and Microplastics: An Assessment of the Effectiveness of Relevant International Regional and Subregional Governance Strategies and Approaches' UN Doc UNEP/EA.3/INF/5 (5 October 2017) 49.

${ }^{22}$ UNEP (n 18) 30, 32. The term RSP is used when we refer to the whole Regional Seas Programme which consists of 18 individual regional seas programmes. When we discuss individual programmes of RSP, we refer to 'a regional seas programme'. See <https://www.unenvironment.org/explore-topics/oceans-seas/what-wedo/working-regional-seas/why-does-working-regional-seas-matter>.

${ }^{23}$ A Boyle, 'Further Development of the Law of the Sea Convention: Mechanisms for Change' (2005) 54 International and Comparative Law Quarterly 563, 575-576.

${ }^{24}$ UNEP (n 18) 10, 17.
} 
regional rivers authorities/commissions, in the development and implementation of regional programmes of action'. ${ }^{25}$ As far as collaboration in relation to riverine inputs of plastics is concerned, the regional river basin organisations (RBOs) and regional seas organizations (RSOs) are the most relevant actors. In fact, within the current international legal framework such cooperation provides the only viable channel for States to fulfil their obligation to prevent, reduce and control pollution from rivers under the LOSC and the RSP, and to follow up on the recommendations of the GPA and the Montreal Guidelines.

\subsection{How does international water law contribute to protecting the marine environment?}

International water law is the legal area that regulates the non-navigational uses and protection of international watercourses. We count around 263 such international watercourses today, on the territories of 145 States. $^{26}$ In addition to ensuring the equitable sharing of freshwater, watercourse States are under clear obligations to protect other watercourse States from significant transboundary harm, and to protect and preserve the ecosystem of an international watercourse. The watercourse's terminus in the sea constitutes an evident connection between the environmental governance of international watercourses and marine pollution and governance. Two global conventions are applicable in this field, besides a number of bi- and multilateral treaties and customary obligations. This section examines how the UNWC and the UNECE Water Convention apply to the connection between fresh and salty water and what legal obligations watercourse States have towards protecting the marine environment.

The UNWC was adopted by the United Nations General Assembly in 1997, as a result of a three decade long drafting process by the International Law Commission (ILC), and entered into force in 2014 as a framework convention that contains both codification of customary principles of international water law as well as more progressive rules. ${ }^{27}$ The provisions of the UNWC apply to 'uses of international watercourses and of their waters for purposes other than navigation and to measures of protection, preservation and management related to the uses of those watercourses and their waters'. ${ }^{28}$ The main scope of the convention is thus the international watercourse, defined as a 'system of surface waters and groundwaters constituting by virtue of their physical relationship a unitary whole and normally flowing into a common terminus' that is situated on the territory of two or more States. ${ }^{29}$ Although the definition alludes to the terminus of a watercourse, the Convention does not provide any further detail on the relationship between the watercourse and its terminus or a definition of what such a terminus is. Article 23, however, establishes an obligation for watercourse States individually or jointly to 'take all measures with respect to an international watercourse that are necessary to protect and preserve the marine environment, including estuaries'. ${ }^{30}$ This provision calls attention to the connection between watercourses and the marine environment and the impact that watercourse pollution can have on the latter. In its commentary to the draft articles, the ILC underlines that the provision does not contain a commitment to protect the marine environment as such, but a duty to manage the watercourse in a manner that does not harm that environment. ${ }^{31}$ Through Article 23, protecting the marine environment is a duty separate from the obligations not to cause significant transboundary harm (Article 6), and to prevent, reduce

\footnotetext{
${ }^{25}$ UNEP (n 18) 18.

$26<$ http://www.unwater.org/water-facts/transboundary-waters/>.

${ }^{27} \mathrm{~S}$ McCaffrey, The Law of International Watercourses (Oxford University Press 2007) 359ff.

${ }^{28}$ United Nations Convention on the Law of the Non-navigational Uses of International Watercourses (adopted 21 May 1997, entered into force 17 August 2014) art 1(1).

${ }^{29}$ ibid art 2(a) and (b).

30 ibid art 23.

${ }^{31}$ ILC 'Yearbook of the International Law Commission 1994, Vol. II Part 2' UN Doc A/CN.4/SER.A/1994/Add.1 (1994) 124.
} 
and control pollution in an international watercourse (Article 22), as these obligations address harm to other watercourse States. As the ILC notes, a watercourses State 'could conceivably damage an estuary through pollution of an international watercourse without breaching its obligation not to cause significant harm to other watercourse States' ${ }^{32}$ A pertinent question in this regard is how this provision is complied with, in light of the large volume of marine plastic pollution deriving from international watercourses, and also how such compliance is monitored given that some coastal States are not party to the UNWC.

The UNECE Water Convention was adopted as a regional agreement for the UNECE area in 1992 and was opened for membership to all United Nations Member States through an amendment that entered into force in 2013. ${ }^{33}$ The Convention stresses the importance of environmental protection in the preamble, by emphasizing the need for national and international measures 'to prevent, control and reduce the release of hazardous substances into the aquatic environment and to abate eutrophication and acidification, as well as pollution of the marine environment, in particular coastal areas, from land-based sources'. ${ }^{34}$ Although not explicitly targeting freshwater resources, the preamble highlights the close connection between land-based sources and marine pollution. Marine areas are not 'transboundary waters' as these are defined in Article 1(1), but are included in the larger scope of the convention, presented in Article 2(6). This provision compels the member States to develop policies, programmes and strategies 'aimed at the prevention, control and reduction of transboundary impact and aimed at the protection of the environment of transboundary waters or the environment influenced by such waters, including the marine environment'. ${ }^{35}$ In terms of scope, the UNWC and UNECE Water Convention are similar: they both target the protection and use of international freshwater resources while acknowledging the direct impact such resources can have on the marine environment and the obligation of States to actively reduce this impact. ${ }^{36}$

The UNECE Water Convention, on the other hand, provides a clear cooperative duty toward coastal States through its Article 9(4). Under the convention, member States are obliged to create joint institutions with coordinating and cooperative duties. ${ }^{37}$ These joint institutions are in turn required to 'invite bodies, established by coastal States for the protection of the marine environment directly affected by transboundary impact, to cooperate in order to harmonize their work and to prevent, control and reduce the transboundary impact' ${ }^{38}$ As stated in the convention's implementation guide, this provision is important, since cooperation under the convention also includes the protection of the marine environment. ${ }^{39}$ In order to fully comply with the obligation to protect the marine environment, the Convention's member States must engage with coastal States through their respective joint institutions to coordinate rules and policies, exchange information and make common action plans. This provision thus suggests an answer to the question raised above with regards to compliance with Article 23 of the UNWC: for the latter provision to be truly effective, watercourse States and coastal States must cooperate and coordinate their legal frameworks and action plans.

As a result, no general obligation for watercourse States or RBOs to cooperate with RSOs or coastal States exists. Watercourse States, however, are required to take into account

\footnotetext{
32 ibid.

${ }^{33}$ UNECE 'Amendment to the Water Convention' UN Doc ECE/MP.WAT/14 (12 January 2004).

${ }^{34}$ Convention on the Protection and Use of Transboundary Watercourses and International Lakes (adopted 17 March 1992, entered into force 6 October 1996) 1936 UNTS 269 (UNECE Water Convention) preamble.

35 ibid art 2(6); A Tanzi (ed), Guide to Implementing the Water Convention (UNECE 2013) 14.

${ }^{36}$ A Rieu-Clarke and R Kinna, 'Can Two Global UN Water Conventions Effectively Co-exist? Making the Case for a 'Package Approach' to Support Institutional Coordination' (2014) 23 Review of European, Comparative \& International Environmental Law 15.

${ }^{37}$ UNECE Water Convention (n 34) art 9(2).

38 ibid art 9(4).

${ }^{39}$ Tanzi (n 35) 73.
} 
how a watercourse's use can impact the marine environment and are further encouraged, through the UNECE Water Convention, to interact with coastal States in this process.

\section{INTERACTION BETWEEN REGIONAL SEAS ORGANISATIONS AND WATERCOURSE COMMISSIONS}

A recent UNEP report suggests that regional governance frameworks, such as improved cooperation between RSOs and RBOs, could provide a mechanism to better address transboundary sources of plastic. ${ }^{40}$ In this section, we take a closer look at how this suggestion is incorporated in management regimes in various parts of the world. The regional seas instruments are examined from the viewpoint of how they take into account plastic pollution from watercourses and cooperation with relevant institutions, namely river and river basin commissions. Our main focus is on the regions where a regional seas programme is in place and where there are international watercourses that transport approximately over 1000 tonnes of plastic, or more, yearly to the ocean. ${ }^{41}$ Other regions have been discussed if noteworthy discoveries were made in their approach to protect the marine environment and watercourses in an integrated manner.

The analysis covers regional seas programmes and respective international watercourses in Asia, South and Central America, Europe and North Africa. It is important to note that, except for the Amazon River, most of the polluted international watercourses have their estuaries in regions that have a regional seas programme in place. In addition, the most heavily polluted national rivers and their estuaries are situated in States that are contracting parties to a regional seas programme. ${ }^{42}$ This means that the RSP could play a significant role in promoting an integrated approach to control riverine inputs of marine plastic pollution.

There are three regional seas programmes in Asia: North-West Pacific, East Asian Seas and South Asian Seas. None of these programmes has a regional seas convention in place, and their obligation to protect the marine environment from land-based sources of pollution therefore stems from the LOSC. However, all these regions have general action plans and two of them have specific plans targeted at marine litter. In Asia, the sheer volume of rivers that transport approximately over 1000 tonnes of plastic yearly to the oceans is staggering compared to other parts of the world. ${ }^{43}$ Only three of these watercourses are international: the Amur River, the Mekong River and the Brahmaputra-Ganges River.

The Amur River is situated in the North-West Pacific region (NOWPAP). It is a shared watercourse between China and Russia and transports on a yearly basis over 1000 tonnes of plastic to the ocean. ${ }^{44}$ The management of the Amur River relies on bilateral action between the two countries and has no RBO. ${ }^{45}$ The NOWPAP Regional Action Plan on Marine Litter encourages its States to 'develop the national plans on the Integrated Coastal Area and River Basin Management (ICARM) where the marine litter issues should be included'. ${ }^{46}$ It also states that these plans should include 'local planning and management capacity to avoid location of

\footnotetext{
${ }^{40}$ UNEP, 'Marine Plastic Debris \& Microplastics: Global Lessons and Research to Inspire Action and Guide Policy Change' (2006) 119.

${ }^{41}$ The analysis has been done by using an interactive map that has modelled riverine inputs of plastics, based on Lebreton et al (n 1), see <https://www.theoceancleanup.com/sources/>. We compared the interactive map with Google Maps to identify the rivers and their locations.

42 ibid.

43 ibid.

44 ibid.

${ }^{45}$ See N Pervushina, 'Water Management and Use in the Amur-Heilong River Basin: Challenges and Prospects in Environmental Security' in V Lagutov (ed), Environmental Security in Watersheds: The Sea of Azov (Springer 2012) 223

${ }^{46}$ NOWPAP, 'Regional Action Plan on Marine Litter' (2008) 5.
} 
waste dump sites near coastlines or waterways as well as to avoid litter escape to the marine and coastal environment'. ${ }^{47}$ To what extent these measures have been adopted remains questionable and since no RBO is in place, answering this question is beyond the scope of this article.

In the East Asian Seas, one international watercourse exists in the region, the Mekong River, which transports approximately over 10000 tonnes of plastic yearly to the ocean. ${ }^{48}$ The East Asian Seas Region has no marine litter action plan. Its Regional Programme of Action mentions the need for integrated catchment and coastal planning but makes no reference to marine litter or plastics specifically. ${ }^{49}$ The report on marine litter in the East Asian Seas proposes as an action to 'encourage and assist municipal councils in each country to implement litter prevention and interception systems in urban catchments, by sharing information on the use of engineering and non-engineering approaches, including but not limited to litter booms, physical traps/interceptors, Stormwater Quality Improvement Devices (SQIDs) and similar measures' ${ }^{50}$ The Mekong River Protection Agreement does not refer to protection of the marine environment, although it does mention protecting the river basin from pollution. ${ }^{51}$ Enhanced cooperation between the Coordinating Body of the Seas of East Asia (COBSEA) and the Mekong River Commission could create an effective mechanism to combat marine plastic pollution in the region.

The most polluting international watercourse is the Brahmaputra-Ganges River, which has its estuary in the South Asian Seas region, and through which over 100000 tonnes of plastic flow to the ocean yearly. ${ }^{52}$ The South-Asia Co-operative Environment Programme's (SACEP) report on marine litter stated that 'numerous cities and industries with inadequate waste management are situated along major rivers such as the Ganges, Narmada, Brahmaputra, Indus, Kelaniya and Mahaweli'. ${ }^{53}$ The report also acknowledges that many of the hotspots of pollution "include areas near the mouths of rivers situated in numerous cities"" ${ }^{54}$ As a way forward, the report suggests 'reducing land-based waste and litter through application at national and regional levels, the Integrated Solid Waste Management (ISWM) focusing on river litter and coastal litter management based on the Three Rs' Approach of Reducing, Re-using and Recycling waste in the SAS region'. ${ }^{55}$ As the Brahmaputra-Ganges River system has no RBO, ${ }^{56}$ cooperation in the region falls under the umbrella of SACEP and thereby involves only coastal States in the region.

In South and Central America, riverine inputs of plastics remain relatively low compared to Asia. ${ }^{57}$ The general obligation to control land-based sources of pollution in the Wider Caribbean region is set forth in the Cartagena Convention and its protocol on land-based sources of pollution. ${ }^{58}$ It has been highlighted in the review of marine litter in the Wider Caribbean that

\footnotetext{
47 ibid 7-8.

48 See $n 41$.

${ }^{49}$ COBSEA/UNEP, 'The Regional Programme of Action for the Protection of the Marine Environment of the East Asian Seas from the Effects of Land-Based Activities' (2000) 11.

${ }^{50}$ COBSEA/UNEP, 'Marine litter in the East Asian Seas Region' (2008) 32.

${ }^{51}$ Agreement on the Cooperation for the Sustainable Development of the Mekong River Basin (adopted 5 April 1995) 2069 UNTS 3 art 3.

${ }^{52}$ See $n 41$.

${ }^{53}$ SACEP 'Marine Litter in the South Asian Seas Region' (2007) iii.

54 ibid 9.

55 ibid 88 .

${ }^{56}$ See AK Biswas, 'Management of Ganges-Brahmaputra-Meghna System: Way Forward' in O Varis, AK Biswas and C Tortajada (eds), Management of Transboundary Rivers and Lakes (Springer 2008) 143.

57 See $n 41$.

${ }^{58}$ Convention for the Protection and Development of the Marine Environment in the Wider Caribbean Region

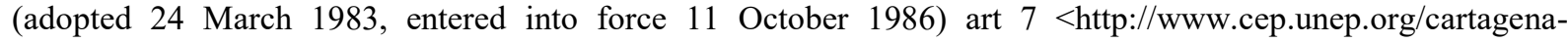
convention/text-of-the-cartagena-convention>; Protocol Concerning Pollution from Land-Based Sources and
} 
'watershed dynamics related to freshwater entry from rivers and canals into the ocean are also important within the region as they relate to land-based sources of marine litter' ${ }^{59}$ There are only two international watercourses in this area that transport roughly over 1000 tonnes of plastic yearly to the ocean. ${ }^{60}$ The first of these examples is the Motagua River, which is a shared watercourse between Honduras and Guatemala. In spite of action to combat pollution in the region by different organizations and governmental and municipal actors, the river's management is not organized under one institution. ${ }^{61}$ The second example is the San Juan River, which is a shared watercourse between Costa Rica and Nicaragua. Before the recent conflicts, ${ }^{62}$ the two States cooperated in developing a strategic action plan for the San Juan River Basin and aspired to establish binational institutional arrangements to execute the plan. ${ }^{63}$ By creating a connection between the regional coordination unit for the Wider Caribbean and the binational institutional arrangements relating to the San Juan River Basin, a common action plan could advance the efforts for a more integrated approach in the region and for bringing awareness to riverine inputs of marine plastic pollution.

In Europe and North Africa, regional seas programmes have been developed for the Mediterranean Sea and the Black Sea, which are semi-enclosed seas, and for the North-East Atlantic (OSPAR). The general obligation to control land-based sources of pollution in these regions derives from the Barcelona Convention, the Bucharest Convention, and the OSPAR Convention, with their respective protocols on land-based sources of pollution. ${ }^{64}$

In the Mediterranean Sea, the regional plan on marine litter management is binding, and according to the regional plan, contracting States must 'by the year 2020 take necessary measures to establish as appropriate adequate urban sewer, wastewater treatment plants, and waste management systems to prevent runoff and riverine inputs of litter' ${ }^{65}$ Article 18 of the plan also encourages cooperation with other relevant institutions in the region to combat marine litter. ${ }^{66}$ Two rivers empty into the Mediterranean Sea - the Nile and the Orontes rivers - both of which are international watercourses that transport over 100 tonnes of plastic yearly to the Mediterranean Sea. ${ }^{67}$ The Orontes River is managed through bilateral means between the

\footnotetext{
Activities (adopted on 6 October 1999, entered into force 13 August 2010) < http://www.cep.unep.org/cartagenaconvention/lbs-protocol/lbs-protocol-english/view>

59 CEP 'Marine Litter in the Wider Caribbean: Regional Overview and Proposed Action Plan' 3, $<$ http://www.cep.unep.org/content/about-cep/amep/marine-litter-in-the-wider-caribbean-a-regional-overviewproposed-action-plan/view>.

${ }^{60}$ See $\mathrm{n} 41$.

$61<$ http://www.summitfdn.org/mesoamerican-reef/the-rule-of-law-and-public-participation-to-protect-themesoamerican-reef/ $/$.

${ }^{62}$ Construction of a Road in Costa Rica along the San Juan River (Nicaragua v Costa Rica) (Judgment) [2015] ICJ Rep 665.

${ }^{63}$ Organization of American States, 'Procuenca San Juan: An Eco-Management Vision for the Integrated Management of Water Resources and the Sustainable Development of the San Juan River Basin and Its Coastal Zone' (October 2005) <http://www.oas.org/dsd/Events/english/Documents/OSDE_5SanJuan.pdf $>$.

${ }^{64}$ Convention for the Protection of the Mediterranean Sea against Pollution (adopted 16 February 1976, entered into force 12 February 1978) 1102 UNTS 27 art 8; Protocol for the Protection of the Mediterranean Sea against Pollution from Land-Based Sources and Activities (adopted 16 February 1976, entered into force 27 February 1983, amended 7 March 1996) 1328 UNTS 120; Convention on the Protection of the Black sea Against Pollution (adopted 21 April 1992, entered into force 14 April 1994) 1764 UNTS art VII; Protocol on Protection of the Black Sea Marine Environment Against Pollution From Land Based Sources (adopted 21 April 1992, entered into force 15 January 1994) <http://www.blacksea-commission.org/_convention-protocols.asp>; Convention for the Protection of the Marine Environment of the North East Atlantic (adopted 22 September, entered into force 25 March 1998) 2354 UNTS 67 art 3, Annex I.

${ }^{65}$ UNEP 'Regional Plan for the Marine Litter Management in the Mediterranean' UN Doc UNEP(DEPI)/MED WG. 379/5 (2013) art 9(4).

${ }^{66}$ ibid art 18.

${ }^{67}$ See $\mathrm{n} 41$.
} 
watercourse States and has no RBO in place. ${ }^{68}$ The management of the Nile, however, is coordinated through the Nile Basin Initiative (NBI) ${ }^{69}$ In its environmental and social policy, the Initiative acknowledges that pollution is increasing in the Nile, ${ }^{70}$ yet none of its schemes address plastics specifically or make reference to protecting the Mediterranean Sea. ${ }^{71}$ Considering the estimated riverine inputs of plastics from the Nile, and the existence of institutions in these regions that could potentially collaborate, enhanced cooperation between the coordinating unit of the regional seas convention and the Nile Basin Initiative could provide an ideal opportunity to tackle and combat riverine inputs of plastics in the Mediterranean Sea.

In the Black Sea Region, the Danube River transports over 100 tonnes of plastic yearly to the Black Sea. ${ }^{72}$ The interconnectedness between the Black Sea and the Danube River is recognized within both regimes. The Danube River Protection Convention endeavours 'to contribute to reducing the pollution loads of the Black Sea from sources in the catchment area'. ${ }^{73}$ The Black Sea Commission and the International Commission for the Protection of the Danube River have agreed in their Memorandum of Understanding (MoU) to combine efforts to control riverine inputs of pollution reaching the Black Sea, ${ }^{74}$ and have established an ad hoc Danube/Black Sea Joint Technical Group to implement the MoU. ${ }^{75}$ The Black Sea Commission has conducted a report on marine litter in the Black Sea region and among its recommendations it is suggested that existing institutional arrangements should be strengthened to combat marine litter. $^{76}$ Therefore, these already existing linkages between the Black Sea Commission and the Danube Commission can prove to be valuable for more targeted action to combat riverine inputs of plastics. This cooperation also serves as a great example for other regions on how they could improve the linkages between RBOs and RSOs.

In the North-East Atlantic Region, the Rhine River transports approximately over 1000 tonnes of plastic to the Atlantic yearly. ${ }^{77}$ The Marine Litter Action Plan in the region highlights 'the importance of cross-sectoral cooperation and implementation of the regional action in close collaboration with other relevant institutions, including river and river basin commissions' ${ }^{78}$ The action plan provides that States must seek 'cooperation in the river and river basin authorities in order to include impacts of litter on the marine environment in river and river basin management plans'. ${ }^{79}$ The International Commission for the Protection of the Rhine considers protection of the North Sea as an additional dimension of its international cooperation, ${ }^{80}$ and the Convention for the Protection of the Rhine has included this aim in the treaty text. ${ }^{81}$ The linkage between the work of the OSPAR Commission and the Rhine Commission is exemplary of well-established cooperation and mutual recognition in protecting

\footnotetext{
${ }^{68}$ T Kaissi, 'Invalidating the Orontes River Treaty in the Context of Middle Eastern Politics' (2014) 26 Georgetown International Environmental Law Review 175.

$69<$ http://www.nilebasin.org/>.

${ }^{70}$ NBI, 'Environmental and Social Policy' (2013) 1, 8.

${ }^{71} \mathrm{NBI}$, 'Transboundary Policies'<http://www.nilebasin.org/index.php/transboundary-policies>.

${ }^{72}$ See $n 41$.

${ }^{73}$ Convention on Cooperation for the Protection and Sustainable Use of the Danube River (adopted 29 June 1994, entered into force October 1998) CELEX 21997A1212(03) art 2.

${ }^{74}$ Memorandum of Understanding between the International Commission for the Protection of the Black Sea and the International Commission for the Protection of the Danube River on Common Strategic Goals (2001).

${ }^{75}$ The Black Sea Commission, 'Marine Litter in the Black Sea Region' (2009) Chapter $3<$ http://www.blackseacommission.org/_publ-ML-CH3.asp>.

76 ibid.

77 See n 41.

${ }^{78}$ OSPAR Commission, 'Marine Litter Regional Action Plan' (2014) 7.

79 ibid 14.

${ }^{80}$ Convention for the Protection of the Rhine (adopted 12 April 1999, entered into force 1 January 2003) CELEX 22000A1116(01)

${ }^{81}$ ibid art 3(5).
} 
the environment. Such cooperation can prove to be valuable in future efforts to reduce riverine inputs of marine plastic pollution in the region.

The cooperation between RSOs and RBOs in the North-East Atlantic and Black Sea regions are by far the best examples of a well-established integrated approach to protecting both river and marine environments. In the Mediterranean, East Asian Seas and the Wider Caribbean, institutions are in place but they have not adopted a common approach to address pollution in general or plastics. In other regions, only RSOs are in place and collaboration with RBOs is not even a possibility. As we argued in the previous section, coastal States are under an obligation to prevent, reduce and control land-based pollution from rivers and estuaries, and watercourse States have a similar obligation to protect the marine environment. The RSP remains the main channel to implement the LOSC provisions on land-based sources of pollution and the GPA on a regional level. It is evident from the analysis in this section that despite the existence of general obligations to both coastal and watercourse states, an integrated approach to protect international watercourses and oceans is not a common rule but rather an exceptional practice.

\section{THE INADEQUACY OF PARALLEL REGIMES}

The examination of regimes in the previous section reveals inconsistencies in the global approach to marine plastic pollution, and helps us illustrate two essential aspects that contribute to the complexity of the problem: (i) the process of fragmentation of international environmental law into different treaty regimes with very little interaction; and (ii) the strong interdependency of States when facing transboundary or global environmental collective action problems such as pollution of watercourses and the marine environment.

The specialization of international environmental law is part of the general tendency of fragmentation in international law, where legal sub-fields are created and developed separately from each other. As a fragment of the more general corpus of international law, international environmental law is experiencing further fragmentation into more specialized environmental sub-fields in accordance with the increased awareness and research on environmental challenges. As the ILC has observed, the problem with legal fragmentation is that 'such specialized law-making and institution-building tends to take place with relative ignorance of legislative and institutional activities in the adjoining fields and of the general principles and practices of international law' ${ }^{82} \mathrm{~A}$ long term risk from this development is naturally the loss of an overall perspective and a uniform understanding of the general principles of international law, or, in this case, the general principles of international environmental law. For instance, the legal fields of international water law and maritime environmental law both belong to the larger body of international environmental law and are based on the same general legal principles, i.e., the duty to reduce transboundary harm, the precautionary principle and the polluter pays principle. ${ }^{83}$ Although sharing the same general values, the coastal States and the watercourse States do not necessarily share the same interests. ${ }^{84}$ While coastal States are not in a position to reduce plastics deriving from watercourses, they are exposed to the impact from such pollution. Watercourse States, on the other hand, are also affected by plastics while it is in situ in the watercourse, but as the plastic flows down-river, the State is no longer directly affected.

\footnotetext{
${ }^{82}$ ILC 'Fragmentation of International Law: Difficulties Deriving from the Diversification and Expansion of International Law' UN Doc A/CN.4/L.682 (13 April 2006) 11.

${ }^{83}$ The polluter pays principle derives from Principle 16 of the 1992 Rio Declaration and implies that the polluter should bear the costs of pollution; however, the principle is not recognized as customary international law. See $U$ Beyerlin, 'Different Types of Norms in International Environmental Law Policies, Principles and Rules' in D Bodansky, J Brunnée and E Hey (eds), The Oxford Handbook of International Environmental Law (Oxford University Press 2008) 441.

${ }^{84} \mathrm{~S}$ Vinogradov, 'Marine Pollution via Transboundary Watercourses - An Interface of the 'Shoreline' and 'RiverBasin' Regimes in the Wider Black Sea Region’ (2007) 22 International Journal of Marine and Coastal Law 585.
} 
Moreover, the watercourse States also enjoy the benefit of polluting and thus have less economic motivation for investing in better waste management systems. This situation thus also illustrates the more concrete problems with fragmentation, as pinpointed by the ILC: possible conflicts between treaty regimes or sub-fields of international law and the overlap of legal rules between such systems.

In this context, legal conflicts can be understood as situations where two rules or principles from separate sub-fields suggest different ways of dealing with a problem. Legal overlaps, on the other hand, appear when similar or identical obligations are contained in instruments that belong to separate legal sub-fields, and must be assessed and complied with within each of these separate instruments. ${ }^{85}$ However, when dealing with marine plastic pollution from international watercourses, we identify a third problematic aspect of legal fragmentation, namely the situations where two parallel legal regimes create legal 'blind spots', i.e. issues or areas that arise in the transition between the regimes, but remain unregulated in both. The problem of pollution is well addressed in both marine environmental law and international water law, and both sub-fields outline clear obligations for their members to prevent, control and reduce discharge of plastic items and pollution in general. However, both fail to address the link between them and how they relate to and influence each other. In the case of marine plastic pollution deriving from watercourses we can even determine a physical link between the two regimes - the passage of freshwater into the sea, which is the point where plastic pollution goes from being the watercourse States' responsibility to becoming the coastal States' responsibility, or from being regulated by the corpus of international water law to being regulated by the law of the sea. These unregulated links thus become blind spots of international law, on the boundary between the two sub-fields. The absence of legal interaction in these blind spots creates legal shortcomings and environmental deterioration that go against the main interests, principles and values in both sub-fields.

One plausible alternative to overcome these legal blind spots is to enforce the recommendations and suggestions made by UNEP and the GPA concerning the interaction, coordination and cooperation between RBOs and RSOs. Although many regimes acknowledge that watercourses are a significant source of marine plastic pollution, only a very small number have taken concrete action to coordinate management and environmental protection of their shared watercourses and coastal areas. The legal connection made in the Black Sea cooperation and in the Rhine cooperation are good examples of institutionalized obligations to cooperate, which can be further strengthened by determining tangible standards and goals. A legal duty to interact could create a regional dialogue concerning the shared problem of plastic pollution, and also increase the possibility of joint monitoring and common action plans. Another alternative could be to create new regimes for environmental protection of water resources that encompass the whole water cycle, from the watercourse's point of origin, the whole basin including groundwater, and the area where the watercourse terminates in the sea, extending into the area of the RSO. For aspects of general management and utilization such a geographical scope might be too vast, as the uses of these different water resources vary greatly and interact very little. However, in an environmental context it is more logical as such a holistic scope can be better suited to address the link between the two disciplines of international water law and ocean law and create consistent regulations and action plans for the whole water cycle.

The second essential aspect that contributes to the complexity of the marine plastic pollution problem is the interdependency of States in mitigating its implications and finding a solution. As the analysis earlier in this article revealed, the problem with marine plastic pollution is that it does not only cross State borders, but also the borders between different subfields of international law. This illustrates the transboundary nature of contemporary

\footnotetext{
${ }^{85}$ ILC (n 82) 12-17.
} 
environmental issues and the interdependency between States in the face of these issues. The problem of marine plastic pollution is a global one, as its consequences can be experienced firsthand by all coastal States and the reversing or mitigation of the problem requires collective action. Unilateral action as a response to the global marine plastic problem would be futile, ${ }^{86}$ and even action taken by a large number of States may be inadequate if sufficiently many States do not cooperate and remain unbound by a possible agreement. Even regional agreements might be ineffective, when considering that microplastics are detected in fish and seafood and thus can export microplastics to other parts of the world, and also to landlocked States. ${ }^{87}$ As an example, European seafood consumers can ingest up to 11,000 microplastics per year. ${ }^{88}$ The global extent of the marine plastic problem creates a strong interdependency between all States in finding a solution. We therefore stress the necessity of quickly initiating an international discourse with the aim of creating a global regime for the reduction and prevention of marine plastic pollution and its negative consequences.

To illustrate the urgency of the marine plastic pollution problem, we draw a parallel to the global climate change regime. Both marine plastic pollution and climate change are collective action problems with a global reach. The efficiency and effectiveness of measures to control, protect and prevent depends on the number of participating States, and of the polluting abilities of those States that choose to remain on the outside of a global regime. In both cases the interdependency among States is high, as the negative impacts are not necessarily experienced in the areas they are caused, and unilateral action is useless. Moreover, both climate change and marine plastic pollution bring severe, and still largely undiscovered, impacts. In the case of climate change, early research and estimates have proven too careful and it is argued that the more extreme climate models will be the most accurate ones. ${ }^{89}$ As marine plastic pollution still is a rather recently discovered problem, the research on its possible or likely impact on ecosystems, animals and human health is still in its early stages. But the main question with regards to its impact is not whether marine plastic pollution is damaging but how severely this damage can alter and harm the health of humans and ecosystems.

\section{CONCLUSIONS}

The problem of marine plastic pollution is addressed either specifically or more generally in a number of different legal instruments belonging to different sub-fields of international environmental law. However, as these instruments and legal regimes lack formal and institutionalized interaction, they create legal blind spots, where the problem of plastic pollution that begins in one regime and enters another remains unaddressed. Such legal blind spots constitute a risk to the overall efficiency and effectiveness of regime-based management, especially with regard to mitigating and reducing marine plastic pollution. Although the global problem of marine plastic pollution cannot be solved by law alone, law can make a valuable contribution by creating a global cooperative regime for surveillance and reduction of marine plastic pollution, as has been done to halt climate change. Moreover, law can institutionalize interaction and create common action plans between regimes of marine environmental law and international water law. When made legally binding and with tangible goals for mitigation and

\footnotetext{
${ }^{86}$ See, e.g., Perrez' comparison of the amount of interdependency and the level of cooperation: FX Perrez, Cooperative Sovereignty: From Independence to Interdependence in the Structure of International Environmental Law (Kluwer Law International 2000) 223ff.

${ }^{87}$ L Van Cauwenberghe and CR Janssen, 'Microplastics in Bivalves Cultured for Human Consumption' (2014) 193 Environmental Pollution 65; MS Savoca et al, 'Odours from Marine Plastic Debris Induce Food Search Behaviors in a Forage Fish' (2017) 284 Proceedings of the Royal Society B.

${ }^{88}$ Van Cauwenberghe and Janssen (n 87) 68.

${ }^{89}$ PT Brown and K Caldeira, 'Greater Future Global Warming Inferred from Earth's Recent Energy Budget' (2017) 552 Nature 45,49 .
} 
reduction of marine plastic pollution, such cooperation can eliminate the gaps between subfields and secure holistic management of a water system and the areas affected by its utilization.

From a global perspective, both aspects of legal fragmentation and global State interdependency must be addressed when seeking a solution to the problem of marine plastic pollution. To tackle a problem that affects the whole water cycle, law cannot be fragmented but must take a holistic approach. Only then can we bridge the gaps between legal sub-fields and address the problem of marine plastic pollution on and across all relevant levels and scales. A good place to start can be to create a clear legal obligation for watercourse States to protect the marine environment, following the example of cooperation on the Rhine River, or to establish more elaborate technical and scientific cooperation, as is done between the Black Seas Commission and the International Commission for the Protection of the Danube River.

Linda Finska is a PhD Candidate in the field of international environmental law at the K. G. Jebsen Centre for the Law of the Sea and the Faculty of Law in the Arctic University of Norway. Her $\mathrm{PhD}$ project focuses on marine plastic pollution prevention.

Julie Gjørtz Howden is a $\mathrm{PhD}$ candidate in international water law and international environmental law at the Faculty of Law, University of Bergen.

The authors owe many thanks to Onni Irish, Henrik Ringbom and Ingvild Jakobsen for valuable comments and input to drafts of the article. 